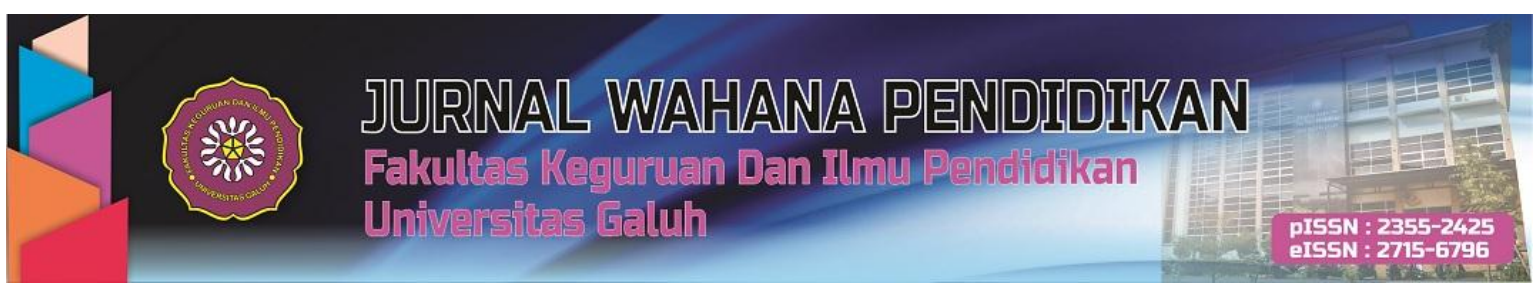

https://jurnal.unigal.ac.id/index.php/jwp

\title{
PENGARUH MODEL CONTEXTUAL LEARNING PADA PELAJARAN PENDIDIKAN KEWARGANEGARAAN DI MADRASAH IBTIDAIYAH AL-IKHWAN KELAS IV
}

\author{
Heri Hidayat, Alfan Siti Qurrotul Aini, Heny Mulyani, Arlin Sircahyati, Desi Nuraisyah \\ Universitas Islam Negeri Sunan Gunung Djati Bandung, J. A.H. Nasution No.105, Kota Bandung \\ Email: alfanqurrotulaini@gmail.com
}

\begin{abstract}
This study aims to determine the effect of the contextual teaching-learning model on citizenship education in Madrasah Ibtidaiyah Al-lkhwan class IV. The contextual teaching-learning method helps teachers links material which is taught with students' real-world situations. So, the knowledge which is obtained can be well embedded and not easily forgotten by the students. When the students find a concept, they experience it themselves through the process of observing, feeling, and experimenting. Therefore, this method will also attract the attention of the students because they feel directly in an environment that is familiar with their lives and can foster a love for their motherland and environment.
\end{abstract}

Keywords: contextual teaching-learning, citizenship education

\section{ABSTRAK}

Penulisan ini bertujuan untuk mengetahui pengaruh model pembelajaran contextual teaching learning pada pelajaran pendidikan kewarganegaraan di Madrasah Ibtidaiyah Al-Ikhwan kelas IV, metode pembelajaran contextual teaching learning ini sebagai bentuk pembelajaran yang membantu guru mengaitkan antara materi yang diajarkan dengan situasi di dunia nyata siswa. Maka pengetahuan yang diperoleh dapat tertanam dengan baik dan tidak mudah dilupakan oleh siswa. Karena saat menemukan suatu konsep mereka mengalami sendiri baik melalui proses mengamati, meraba, merasa, maupun bereksperimen. Sehingga metode ini juga menarik perhatian siswa karena siswa merasa dibawa langsung ke lingkungan yang telah akrab dengan kehidupannya dan dapat menumbuhkan kecintaan pada tanah air maupun lingkungannya.

Kata Kunci: contextual teaching learning, pendidikan kewarganegaraan

Cara sitasi:

Hidayat, H., Aini, A. S. Q., Mulyani, H., Sircahyati, A., \& Nuraisyah, D. (2020). Pengaruh model contextual learning pada pelajaran pendidikan kewarganegaraan di madrasah ibtidaiyah al-ikhwan kelas iv. Jurnal Wahana Pendidikan, 7(1), 9- 


\section{PENDAHULUAN}

Ada pepatah mengatakan "dimana bumi di pijak di situ langit di jungjung" bukan hanya sekedar kutipan belaka namun dapat di artikan bahwa kita sebagai warga negara patut menghargai, menjungjung tinggi, memajukan, menjaga nama baik Indonesia yang sudah di perjuangkan kemerdekaaannya oleh para pahlawan. Oleh karena itu kita sebagai warga negara yang akan menjadi seorang pendidik harus mengajarkan nilai-nilai patriotisme dan kerja sama dalam kehidupan.

Dahulu para pahlawan melawan penjajahan menggunakan senjata dan bertaruh nyawa, namun sekarang penjajah menyerang menggunakan teknologi modern untuk mengalihkan warga negara kita harus melawan penjajahan dimulai dari diri sendiri dengan belajar melawan kebodohan dan mencerdaskan generasi penerus bangsa.

Belajar adalah suatu proses dan aktivitas yang selalu dilakukan oleh manusia yang dapat mencerdaskan bangsa dimulai dari dalam kandungan, balita, anak-anak, dewasa, tua sampai liang lahat. Belajar merupakan usaha memperoleh perubahan tingkah laku seorang individu. Oleh karena itu guru sebagai pendidik harus mampu dan berupaya menciptakan pembelajaran yang menggugah motivasi belajar murid, yang pada akhirnya mendapatkan hasil belajar yang maksimal dan pendidik senantiasa memberikan dorongan dan semangat pada murid, mengupayakan proses belajar yang menarik yang merangsang hasil belajar murid menjadi lebih baik.

Model pembelajaran itu merupakan suatu kerangka konseptual yang prosedurnya sistematis serta dalam pengorganisasian pengalaman belajarnya mencapai tujuan belajar. Model pembelajaran ini memiliki unsur-unsur yang mendasar yaitu: (1) syntax, yaitu langkah-langkah operasional. (2) social system, merupakan suasana dan norma yang berlaku dalam pembelajaran, (3) principles of reaction, menggambarkan sebagaimana harusnya guru mrmandang, memperlakukan, dan merespon para siswa. (4) support system, merupakan segala sarana, alat, bahan serta lingkungan belajar yang mendukung terjalannya pembelajaran, (5) instructional dan nurturant effects, merupakan suatu hasil pembelajaran yang dihasilkan langsung berdasarkan tujuan yang telah ditetapkannya (Kemendikbud 2017).

Pembelajaran contextual teaching learning merupakan suatu konsep dimana pembelajaran tersebut mengaitkan antara materi pembelajaran yang dipelajari siswa dengan konteks materi tersebut di gunakan dengan menggunakan pengalaman dan pengetahuan sebelumnya untuk menemukan dan membangun pengetahuannya sendiri dalam kehidupan sehari-hari. Model contextual teaching learning ini sebagai bentuk pembelajaran yang membantu guru mengaitkan antara materi yang diajarkan dengan situasi di dunia nyata siswa. Peran siswa dalam model pembelajaran contextual teaching learning merupakan sebuah subjek pembelajaran yang menemukan dan membangun sendiri konsep-konsep yang dipelajarinya. belajar bukanlah sekedar membaca, menghafal, dan mengingat fakta-fakta tetapi belajar adalah upaya untuk mengoptimalkan potensi kognitif, afektif, maupun psikomotor.

Priyatni (2002:2) menyebutkan bahwa pembelajaran yang berciri konstruktivisme menekankan terbangunnya pemahaman sendiri secara aktif, kreatif, dan produktif dari pengalaman atau pengetahuan terdahulu dan dari pengalaman belajar yang bermakna. Murid perlu dibiasakan untuk memecahkan masalah, menemukan sesuatu yang berguna bagi dirinya, dan bergelut dengan ide-ide baru.

Oemar Hamalik (2002:2) menjelaskan bahwa "belajar adalah perubahan tingkah laku yang relative mantap berkat latihan dan pengalaman". Belajar sesungguhnya adalah ciri khas manusia dan yang membedakannya dengan binatang. Belajar yang dilakukan manusia merupakan bagian dari hidupnya, berlangsung seumur hidup, kapan saja, dan dimna saja, baik di sekolah, di kelas, di jalanan dalam waktu yang dapat ditentukan sebelumnya. Namun demikian satu hal yang pasti bahwa belajar yang dilakukan manusia senantiasa oleh itikad dan maksud tertentu.

Sanjaya (2005) mengungkapkan bahwa, Contextual Teaching and Learning (CTL) merupakan suatu strategi pembelajaran yang menekankan pada proses keterlibatan siswa secara 
penuh untuk menemukan materi yang dipelajarai dan menghubungkannya dengan situasi kehidupan nyata sehingga mendorong siswa untuk dapat menerapkannya dalam kehidupan mereka.

Kemudian menurut Nurdyansyah \& Fahyuni (2016) seorang pengajar yang professional tidak hanya berpikir tentang apa saja yang akan diajarkan dan bagaimana cara pengajarannya, tetapi seorang guru juga harus tau siapa dan bagai mana kondisi murid-murid yang diajarkan, kemudian makna apa yang akan didapatkan murid setelah melakukan pembelajaran, dan kemampuan apa yang dapat dilakukan oleh murid.

Perkembangan tidaklah terbatas dalam arti tumbuh menjadi besar tetapi mencakup rangkaian perubahan yang bersifat progresif, teratur, koheran, dan berkesinambungan. Jadi antara satu tahap perkembangan dengan yang lainnya saling berhubungan. Kemudian perkembangan itu dimulai dari respon yang sifatnya umum menuju yang khusus, dengan adanya stimulus bisa menumbuhkan progress dalam perkembangan kognitif siswa (Gunarsa: 2013)

Permasalahan murid pada umumnya kurang memiliki rasa cinta dan kehormatan kepada tanah air dan kepada guru. Kondisi saat pembelajaran PKn di kelas IV siswa hanya memperhatikan guru yang sedang menerangkan materi dan ada sebagian yang kurang memperhatikan guru. Kemudian untuk mengatasi permasalahan di Madrasah Ibtidaiyah Al- Ikhwan peneliti mewawancarai guru dengan menyarankan metode pembelajaran yang baik untuk di gunakan selain metode ceramah dan tanya jawab yaitu pendidik bisa mengunakan metode CTL (Contextual Teaching Learning). Pendekatan kontekstual merupakan suatu pendekatan yang membantu guru mengaitkan isi materi pelajaran dengan keadaan dunia nyata. Pembelajaran ini memotivasi murid untuk menghubungkan pengetahuan yang diperoleh di kelas, dan penerapannya dalam kehidupan murid sebagai anggota keluarga, serta sebagai anggota masyarakat.

\section{METODE PENELITIAN}

Penelitan ini dilaksanakan dengan menggunakan metode observasi dan wawancara kepada guru di dalam kelas untuk melihat kondisi siswa ketika guru menerangkan materi dan melihat metode yang digunakan guru ketika menerangkan materi pembelajaran.

Awal permulaan kita mengamati kelas IV di Madrasah Ibtidaiyah Al -lkhwan penelitian ini laksanakan dalam satu pertemuan yaitu pada tanggal 21 Novenber 2019 kita melakukan observasi kelas dengan memperhatikan guru dalam mengajar di kelas lalu setelah itu kita melakukan wawancara terhadap guru dengan menanyakan langkah-langkah pembelajaran, materi dan metode yang di gunakan, dan pendapat guru tentang apa saja masalah yang umum yang terdapat pada siswa. Pada tahapan ini dilakukan pengamatan mengenai: (a) Awal proses pembelajaran. (b) merumuskan masalah. (c) Memecahkan masalah dengan metode pembelajaran

Observasi tindakan kelas ini mengikuti kompetensi guru profesional, pedagogik, sosial dan kompetensi kepribadian yang dimana kompetensi tersebut merupakan kemampuan pemahaman terhadap peserta didik, pembelajaran yang mendidik, dan pengembangan pribadi anak untuk berusaha mencapai tujuan pendidikan dan melaksanakan perannya dalam pembelajaran di kelas.

Pembelajaran dan pengajaran contektual teaching learning melibatkan beberapa komponen utama yaitu: (a) kontruktivisme. (b) inkuiri. (c) bertanya. (d) lerning community. (e) permodelan. (f) refleksi. (g) penilaian otentik (Rhiezal; 2019)

Ketika dalam pembelajaran menggunakan metode kontekstual siswa akan mudah memahami pembelajaran pendidikan kewarganegaraan dan memotivasi siswa dalam belajar untuk mencintai tanah air. Karena dalam model kontektual di perkenalkan fakta-fakta kebenaran dalam kehidupan sehari-hari dan juga pengetahuan melalui pengalaman sehingga akan timbul jiwa patriotisme siswa terhadap tanah air.

\section{HASIL DAN PEMBAHASAN}

CTL (contektual teaching learning) adalah suatu proses pendidikan atau proses pembelajaran yang bertujuan untuk memotivasi siswa agar memahami makna materi pelajaran yang 
dipelajarinya dengan mengkaitkan materi tersebut dengan konteks atau keadaan di kehidupan mereka sehari-hari sehingga siswa memiliki pengetahuan, keterampilan, bahkan bisa menjadi agen perubahan bagi lingkungannya yang secara fleksibel dapat diterapkan dari satu permasalahan kehidupan.

Ada tiga hal yang harus dipahami dalam menggunakan CTL (contektual teaching learning). Yang Pertama harus menekankan kepada proses keterlibatan siswa untuk menemukan materi bisa dengan bertanya materi dengan kejadian yang pernah siswa alami. Kedua CTL menuntun agar siswa dapat menemukan hubungan antara materi yang dipelajari dengan situasi kehidupan nyata, artinya siswa dituntut untuk dapat menangkap hubungan antara pengalaman belajar di sekolah dengan kehidupan nyata bisa dengan lingkungan keluarga dan masyarakat. Ketiga CTL memotivasi siswa untuk dapat menerapkan materi yang di pelajari dalam kehidupannya, artinya CTL bukan hanya mengharapkan siswa dapat memahami materi yang dipelajarinya, akan tetapi bagaimana materi pelajaran itu dapat mewarnai dan dapat merubah perilakunya dalam kehidupan sehari-hari. Materi pelajaran dalam konteks CTL bukan hanya untuk pembelajaran di kelas saja atau hanya teori saja dan kemudian dilupakan dan tidak di amalkan atau di praktekan, akan tetapi sebagai bekal siswa dalam mengetahui dan dapat menerapkan kehidupan nyata seperti pada pembelajaran pkn di harapkan siswa lebih cinta terhadap tanah air dengan belajar sungguh-sungguh, betapa pentingnya pelajaran pendidikan kewarganegaraan di ajarkan di madrasah ibtidaiyah sebagai wujud memberi pemahaman dan menumbuhkan kesadaran jiwa bagi peserta didik untuk mengingat kemerdekaan, pada saat itu kemerdekaan bangsa Indonesia di peroleh dengan perjuangan yang keras bahkan nyawa pun di taruhkan, dengan cara kita semangat untuk belajar terutama belajar pendidikan kewarganegaraan itu sudah mewakili bahwa kita cinta tanah air.

Pendidikan kewarganegaraan di Madrasah Ibtidaiyah ini sebagai suatu proses belajar mengajar dalam rangka membantu peserta didik agar dapat belajar dengan baik dan membentuk manusia Indonesia seutuhnya dalam pembentukan karakter bangsa yang diharapkan menjadi masyarakat yang demokratis dalam berbangsa dan bernegara berlandaskan Pancasila dan undungundang (Harudin, 2019). Ruminiati (2007: 26) berpendapat bahwa tujuan pendidikan kewarganegaraan di sekolah dasar ialah untuk menjadikan warga negara yang baik, yaitu warga negara yang tahu, mau dan sadar akan hak dan kewajibannya. Pendidikan kewarganegaraan juga memberikan pelajaran kepada peserta didik untuk memahami dan membiasakan dirinya dalam kehidupan di sekolah maupun di luar sekolah, karena materi pendidikan kewarganegaraan menekankan pada pembiasaan terhadap kehidupan sehari-hari yang ditunjang oleh pengetahuan dan pengertian sederhana untuk mengikuti pendidikan.

Pendidikan kewarganegaraan di sekolah dasar dituangkan dalam lampiran Permendiknas No. 22 tahun 2006, dalam lampiran tersebut dikemukakan bahwa "mata pelajaran pendidikan kewargenegaraan merupakan mata pelajaran yang memfokuskan pada membentukkan warga negara yang memahami dan mampu melaksanakan hak-hak dan kewajibannya untuk menjadi warga negara Indonesia yang cerdas, terampil, dan berkarakter yang diamanatkan oleh Pancasila dan UUD 1945" sedangkan tujuannya digariskan dengan tegas adalah agar peserta didik memiliki kemampuan sebagai berikut: 1 . Berpikir secara kritis, rasional, dan kreatif dalam menanggapi isu kewarganegaraan. 2. Berpartisipasi secara aktif dan bertang- gung jawab, dan bertindak secara cerdas dalam kegiatan bermasyarakat, berbangsa, dan bernegara serta anti korupsi. 3. Berkembang secara positif dan demokratis untuk membentuk diri berdasarkan karakter-karakter masyarakat Indonesia agar dapat hidup bersama dengan bangsa-bangsa lain. 4. Berinteraksi dengan bangsabangsa lain dalam peraturan dunia secara langsung atau tidak langsung dengan memanfaatkan teknologi informasi dan komunikasi.

Sesuai dalam buku Pendidikan Kewarganegaraan (Sunarso Dkk, 2008:01) Pertama, PKn secara kurikuler dirancang sebagai subjek pembelajaran yang bertujuan untuk mengembangkan potensi individu agar menjadi warga negara Indonesia yang berakhlak mulia, cerdas, partisipatif, dan bertanggung jawab. Kedua, PKn secara teoritik dirancang sebagai subjek pembelajaran yang 
memuat dimensi kognitif, afektif dan psikomotorik yang bersifat konfluen atau saling berpenetrasi dan terintegrasi dalam konteks subtansi, ide, nilai, konsep, dan moral pancasila, kewarganegaraan yang demokratis, dan bela negara. Ketiga, secara pragmatik dirancang sebagai subjek pembelajaran yang menekankan pada isi yang mengusung nilai-nilai Content Embedding Values dan pengalaman belajar Learning Experiences dalam bentuk berbagai perilaku yang perlu diwujudkan dalam kehidupan sehari-hari dan merupakantuntutan hidup bagi warga negara dalam kehidupan bermasyarakat, berbangsa dan bernegara sebagai penjabaran lebih lanjut dari ide nilai, konsep, dan moral pancasila, kewarganegaraan yang demokratis, dan bela negara.

Masalah umum pada siswa adalah kurangnya rasa cinta kepada tanah air sehingga seringkali siswa-siswa tidak serius dalam pembelajaran pendidikan kewarganegaraan seperti murid di kelas biasanya siswa kurang aktif, waktu pembelajaran mereka kurang fokus sehingga banyak yang tidak memperhatikan, lalu terjadi pembelajaran yang terasa membosankan.

Kami mewawancarai salah satu guru yang bernama Heri Herlambang yang ada di sekolah swasta yaitu Madrasah Ibtidaiyah Al- Ikhwan yang mengajar di kelas IV yang berjumlah 25 orang siswa yang ada di kelas tersebut. Pada awal pembelajaran, guru memberi materi dengan ceramah dan tanya jawab kepada murid sesuai dengan materi lalu di kaitkan dengan penerapan kehidupan sehari-hari siswa. Pada akhir pembelajaran guru memberikan permainan kepada anakanak,sehingga mereka bersemangat kembali dan mereka terlihat sekali menikmati permainan dengan senang sambil menunggu waktu pembelajaran selesai.

Setelah pembelajaran selesai kami bertanya kepada guru tersebut tentang penerapan model pembelajaran contextual teaching learning yang di terapkan di kelas pada mata pelajaran pendidikan kewarganegaraan, menurut beliau model contextual teaching learning ini dapat meningkatkan hasil belajar siswa dalam mata pelajaran pendidikan kewarganegaraan, siswa lebih mandiri dan lebih mudah mengerti memahami materi yang disampaikan guru karena model ini mengaitkan dalam kehidupan mereka dan lebih aktif dalam memahami mata pelajaran pendidikan kewarganegaraan tersebut dan menimbulkan semangat sehingga tujuan pembelajaran dapat dicapai dengan maksimal contextual teacing learning ini bukan sekedar membaca, mendengarkan, dan mencatat, tetapi menanamkan pengalaman kedalam diri siswa melalui proses belajar secara langsung dengan lingkungan sekitar. Model ini juga salah satu alternatif pembelajaran yang menjadikan siswa bukan hanya aktif saja, tetapi mereka sangat antusias dalam kegiatan pembelajaran tersebut, siswa bukan hanya menghafal materi saja tetapi peserta didik dengan cara belajar mengalami, sehingga pembelajaran tertanam dalam ingatan siswa serta dapat mengaplikasikan materi yang dipelajari dengan kehidupan sehari-hari. Masalah yang dihadapi ketika mengajar apabila anak-anak sudah jenuh tetapi jam pembelajarannya belum beres, kata beliau "guru harus pintar-pintar agar pembelajaran tersebut tidak jenuh dan lebih asik". Beliau mengatasinya dengan ice breaking karena siswa akan lebih menikmati atau dengan cara belajar dan bermain dengan cara tersebut bisa mengembalikan semangat para siswa sambil menunggu jam pelajaran selesai. Menurut pengamat pengaruh pembelajaran metode contextual teaching learning akan tertanam pada siswa jika penyampaian guru dalam mengaitkan materi dengan kehidupan nyata di sampaikan dengan baik dan benar maka kemungkinan ada setidaknya rasa cinta kepada diri sendiri, lingkungan, ataupun negaranya dengan perubahan tingkah laku yang bertahap-tahap dari kurang baik menjadi baik sehinggga berefek pada semangat keinginan siswa untuk belajar dengan baik.

\section{KESIMPULAN}

Berdasarkan observasi yang dilakukan, pelaksanaan pembelajaran menggunakan metode contextual teaching learning dapat meningkatkan semangat belajar peserta didik. Perbedaan pada metode ceramah yang hanya menyampaikan teori saja tanpa mengaitkan dengan kehidupan seharihari,sedangkan yang nampak dalam penggunaan metode contextual teaching learning ini berada pada "bagaimana peserta didik memahami materi pembelajaran yang berkaitan dengan kehidupan 
sehari-hari" jadi pengaruh pada saat metode contextual teaching learning siswa bukan hanya sekedar membaca, mendengarkan,dan mencatat, tetapi menanamkan pengalaman dalam diri siswa dalam proses belajar secara langsung dalam proses belajar melalui permainan ice breaking sehingga siswa menikmati permainan dan memjadi semangat kembali untuk melanjutkan pembelajaran.

\section{REKOMENDASI}

Penulisan rekomendasikan untuk dapat menguji cobakan model pembelajaran contextual teaching learning pada pelajaran pendidikan kewarganegaraan di tingkat sekolah yang lebih tinggi.

\section{UCAPAN TERIMAKASIH}

Terimakasih kepada pihak yang sudah memberikan dukungan pada penelitian ini yaitu Madrasah Ibtidaiyah Al-Ikhwan yang telah memberikan izin lokasi penelitian dan keterlibatan siswa sebagai sampel penelitian dan tidak lupa ucapan terimakasih kepada pihak-pihak yang terkait dalam penelitian ini yang tidak dapat penulis sebutkan sehingga penelitian ini berjalan dengan baik.

\section{DAFTAR PUSTAKA}

Gunarsa, S. D. (2008). Psikologi perkembangan anak dan remaja. BPK Gunung Mulia.

Harudin, K. (2019). Penggunaan Metode Contextual Teaching Learning (Ctl) Tipe Emotional Quotient (Eq) Sebagai Upaya Meningkatkan Hasil Belajar Siswa Pada Pembelajaran Interaksi Sosial Di Kelas Smpit Ishlahul Ummah Boarding School Tasikmalaya. Jurnal Wahana Pendidikan 4 (2), 86-98.

Kemendikbud. (2017). ebook Model-Model Pembelajaran di Sekolah. Modul Kuliah

Nurdyansyah, N., \& Fahyuni, E. F. (2016). Inovasi Model Pembelajaran Sesuai Kurikulum 2013. Sidoarjo: Nizamial Learning Center

Oemar Hamalik. (2004). Perencanaan Pengajaran Berdasarkan Pendekatan Sistem. Jakarta: Bumi Aksara.

Permendiknas No. 22 tahun 2006 tentang Standar Isi: Lampiran Standar Isi Pendidikan

Priyatni, Endah Tri. (2002). Penerapan Konsep Kontekstual dalam Pembelajaran Bahasa Indonesia. Kumpulan Materi TOT CTL Mata Pelajaran Bahasa Indonesia Sekolah Lanjutan Tingkat Pertama. Jakarta: depdiknas.

Rhiezal. (2019). Ebook Model pembelajaran Contextual Teaching. Diktat Kuliah

Ruminiati. (2008). Pengembangan Pendidikan kewarganegaraan SD. Jakarta: Direktorat Jendral Pendidikan Tinggi Departemen Pendidikan Nasional.

Sanjaya. (2005). Pendekatan Contextual Teaching and Learning (CTL). Jakarta: Rafika Media

Sunarso. dkk. (2008). Pendidikan Kewarganegaraan. Yogyakarta: UNY Press 